\title{
Challenges of Internally Displaced Children in Makurdi Metropolis of Benue State
}

\author{
Okonkwo L.E ${ }^{1}$, Nomji, E, $\mathbf{V}^{2}$ \\ ${ }^{1,2}$ Department of Home Science Management, College of Food Science and Technology, Joseph Sarwuan Tarka \\ University Makurdi, Benue state, Nigeria. \\ Corresponding Author: Nomji Vihimga Elijah
}

\begin{abstract}
The study investigates the Challenges of internally displaced children in Makurdi Metropolis of Benue State, Nigeria. Three research questions guided the study. The sample of the study was drawn from children between the ages of 12-18 years living in Internally Displaced Camps (IDPs) in Makurdi. Simple random sampling technique was used to select a sample size of 300 for the study. Primary data were used for the study specifically obtained using well-structured questionnaire titled internally displaced children (IDC), data collected was analysed using mean and standard deviation. Findings of the study on social life of internally displaced children in Makurdi revealed that Lack of finance to celebrate social activities such as birthday parties, naming ceremonies and sports competitions (4.46), Children appear dirty and tattered due to lack of clothing (3.40), also the findings on financial challenges indicates Low level of income due to lack of business and means of livelihood (3.62), Depends on people for financial assistance (begging) (3.58). Furthermore, the study on feeding pattern of internally displaced children shows that children hardly eat twice a day (3.55), lack required food nutrients such as protein, vitamins and minerals (3.40). The study therefore concludes that insecurity challenges should be tackled by government to ensure that household returns to their various communities. Finally the study recommends improvement of social life of internally displaced children should be given uppermost attention the government and non- government organisations responsible for child upbringing. The governments should make frantic effort to ensure adequate provision of basic amenities
\end{abstract}

such as water, food and shelter. Emergency healthcare and education (schools) should be provided in IDPs camps. Good food should be provided for children in internally displaced camps to avoid malnutrition that leads to ill health. Causes insecurity and other crisis that leads to displacement of families should be given lasting solutions by government and communities concerned. The Children should be encouraged to adopt a good environmental sanitation which will go a long way to help prevent them from contracting some sickness and disease.

Keywords- Families, Challenges, Internally, Displaced, Children,

\section{INTRODUCTION}

Internally Displaced persons also known as IDP's are mostly victims of the inhumanity of man against man. They are victims of various kind of injustices or violence confrontations, perpetrated by either their own government against them or by others, such as, family conflicts, communal clashes, terrorism, riots, religious conflicts, natural disasters (Akuto, 2017).

Benue state especially Makurdi metropolis had faced series of conflicts and these conflicts have wrecked havoc to the socio-economic development of the state. The conflicts most especially inter community, inter and intra ethnic conflicts pre-date the colonial era and for long has been a recurrent decimal (Dickson, Danjuma \& Stephen, 2018). These conflicts and other form of social crisis such as flood (common example is the flood of 2017) 
have forced families and their children to leave their homes to seek for shelter and to take refuge somewhere else. Ode (2018) posit that in the past few years, an alarming number of people from Guma, Gwer west, Gwer East, and Agatu local governments of Benue state have had to abandon their homes and livelihoods in the face of Fulani Herdsmen terroristic attacks amidst other threats.

These scenes have led to the formation of different camps to rescue the internally displaced persons in the state. Also, at the heart of the challenges, population displacement become an abhorrent issues, in the midst of these challenges facing families in Makurdi, children mostly suffer the brunt. They are always vulnerable and victims of insecurity and disasters. This has led to street hawking and all other forms of child abuse and abandonment. The most venerable groups are those children who lost their parents as a result of these crises (GRID, 2015). According to Dickson, Danjuma \& Stephen (2018), child abuse manifested in most of the IDPs' camps in the state which often occur in forms of physical violence, neglect, sexual assault, emotional cruelty, child labour, child hawking, confinement, social isolation, repeated verbal abuse, emotional neglect and unaffectionate treatment. Talja (2015) noted that failure to meet child's basic needs, enrolment in school, inadequate supervision and consistent failure to protect the child from hazard and danger can lead to poor growth and development. Christelle (2019) also reported that Internally displaced children are at a higher risk of abuse, neglect and violence, illness and distress, poverty and other harms. These affect their current and future well being.

The study of Christelle (2019) identified various types and mode of discrimination of internally displaced children such as physical, mental, social, cultural, and emotional abuse. Children in IDPs camps are not handicapped by any genetic deficiency but by the socioeconomic circumstances of their lives. The internally displaced children are constantly denied the freedom to enjoy their basic human rights. According to the study of Desai and Kulkarni (2008), internally displaced children are kept away from the main-stream of social activities and were deprived of their basic life amenities and liberty. This tends to keep them at a distance from the society, which affects their economic, social and intellectual capabilities for survival. Among the various problems that affect internally displaced children in Makurdi include homeless, low or lack of education, poor social life, malnutrition, lack of clothing and other necessities for human survival. Cinjel and Akende (2015) reported that the end to inequality is the beginning of development for any nation. The future of any nation is in the hands of children and these internally displaced children are not an exception.

According to Falabi (2014), socioeconomic growth and integration at present economy, present the challenge that children need to be equipped and prepared by means of vocational counselling for skill acquisition and training. This is to prepare them to survive physically, mentally, socially and economically while in camp and when they leave the camps

This study therefore tries to investigate the challenges of internally displaced children in Makurdi Metropolis of Benue State, Nigeria. Emphasis will be given to five (5) major IDPs camps in Makurdi metropolis of Benue State. This will include IBB camp Ichua, Old market camp, Abagema camp, NEPA quarters camp and Ogiri Ajene respectively. The study is spurred by examining the prevalence of poor social life, financial challenges and low feeding pattern experience by children in IDPs camps that results to issues leading to violence, child abuse, that can threaten human survival. The researchers sought possible solutions to ameliorate the plight of internally displaced children in Makurdi Metropolis of Benue State. 
The rest of this paper is organised as follows, section I contains the introduction, section II contains the methods used in investigating the challenges faced by internally displaced children, section III contains result of findings, section IV contains discussion of these findings and finally section $\mathrm{V}$ contains conclusion and recommendations

\section{Research Questions}

The following research questions are developed to guide the study.

1. What are the social lives of internally displace children in Makurdi metropolis of Benue state.

2. What are the financial challenges of internally displaced children in Makurdi metropolis of Benue state.

3. What are the feeding patterns of the internally displaced children in Makurdi metropolis of Benue state.

\section{METHODOLOGY}

This study used descriptive research design to determine the challenges of internally displaced Children in Makurdi Metropolis of Benue State, Nigeria. Simple random sampling technique was used to select sixty (60) respondents from each of the five (5) IDPs camps for the study. A sample size of 300 respondents was used for the research. Twenty eight (28) items were drawn from the research questions. The data collected were analysed using mean and standard deviation to answer the research questions. In taking decisions, any mean below 2.00 was rejected and those above 2.00 was considered accepted.

\section{RESULTS}

Research Question 1: What are the social lives of the internally displaced children in Makurdi Metropolis?

Table1: Mean Responses on the Social life of Internally Displaced Children in Makurdi Metropolis of Benue State.

\begin{tabular}{|c|c|c|c|c|}
\hline $\mathbf{S} / \mathbf{N}$ & Item statement & $\bar{X}$ & Std & Decision \\
\hline 1 & Children experience poor school enrolment & 3.27 & 1.13 & accepted \\
\hline 2 & Children are exposed to high level of discrimination and stigmatization & 3.37 & 1.15 & accepted \\
\hline 3 & Children appear dirty and tattered due to lack of clothing & 3.40 & 1.21 & accepted \\
\hline 4 & Children perceived as rejected due to the environment they live? & 3.34 & 1.22 & accepted \\
\hline 5 & $\begin{array}{l}\text { Lack finance to celebrate social activities such as birthday parties, naming ceremonies and sports } \\
\text { competitions }\end{array}$ & 4.46 & 1.20 & accepted \\
\hline 6 & Children are exposed to high level of insecurity & 2.99 & 1.31 & accepted \\
\hline 7 & Children lack access to basic amenities such as electricity, portable water, food and shelter & 3.20 & 1.21 & accepted \\
\hline 8 & Children are prone to abuse of human rights (child trafficking). & 3.26 & 1.12 & accepted \\
\hline
\end{tabular}

From table 1: The results of the study reveals that all items were accepted by the respondents with the highest mean score of (4.46) Lack finance to celebrate social activities such as birthday parties, naming ceremonies and sports competitions, (3.40)
Children appear dirty and tattered due to lack of clothing respectively.

Question 2: What are the financial challenges of the internally displaced children's family in Makurdi metropolis of Benue State?

Table 2: Mean Response on the Financial Challenges of Internally Displaced Children's Family in Makurdi Metropolis of Benue State.

\begin{tabular}{|l|l|l|l|c|}
\hline S/n & Item statement & $\bar{X}$ & Std & Decision \\
\hline 9 & Experience poor finance as a result of lost of properties & 3.41 & 1.31 & accepted \\
\hline 10 & Low level of income due to lack of business and means of livelihood & 3.62 & 1.34 & accepted \\
\hline 11 & Experience financial difficulties as a result of unmet needs & 3.22 & 1.25 & accepted \\
\hline 12 & Lost of gainful jobs and employment & 3.21 & 1.23 & accepted \\
\hline 13 & Unable to meet up with social and economic obligations & 3.39 & 1.22 & accepted \\
\hline 14 & Have limited access to social-economic activities & 3.22 & 1.36 & accepted \\
\hline 15 & Street hawking and begging by their children & 3.14 & 1.31 & accepted \\
\hline 16 & Unmet health problems that leads to death of family members as a result of poor finance & 3.04 & 1.26 & accepted \\
\hline 17 & have little or no source of income & 2.29 & 1.33 & accepted \\
\hline 18 & Depends on people for financial assistance (begging) & 3.58 & 1.27 & accepted \\
\hline
\end{tabular}


The results of the study on table 2 revealed that all the items were significant factors for financial challenges of internally displaced children in Makurdi Metropolis in Benue State with the highest mean score of (3.62) Low level of income due to lack of business and means of livelihood, (3.58)
Depends on people for financial assistance (begging) respectively.

Question 3: What are the feeding patterns of internally displaced children in Makurdi metropolis of Benue State?

Table 3: Mean Response on the Feeding Patterns of Internally Displaced Children in Makurdi Metropolis of Benue State

\begin{tabular}{|c|c|c|c|c|}
\hline $\mathbf{S} / \mathbf{N}$ & Item statement & $\mathbf{x}$ & Std & Decision \\
\hline 19 & Lack proper feeding practices & 2.97 & 1.23 & accepted \\
\hline 20 & hardly eat twice a day & 3.55 & 1.31 & accepted \\
\hline 21 & Illness as a result of low food calories & 3.39 & 1.30 & accepted \\
\hline 22 & Children lack proper diet & 3.19 & 1.14 & accepted \\
\hline 23 & Children always eat at the wrong time & 3.24 & 1.13 & accepted \\
\hline 24 & Children mostly feeds on starchy food & 3.03 & .23 & accepted \\
\hline 25 & Children experience stunted growth & 3.13 & 1.31 & accepted \\
\hline 26 & Hunger and starvation due to lack of food leads to death of children in IDP camps & 2.97 & 1.30 & accepted \\
\hline 27 & Children always lack access to portable water for drinking & 2.98 & 1.31 & accepted \\
\hline 28 & lack of required food nutrients like proteins, vitamins and minerals & 3.40 & 1.13 & accepted \\
\hline
\end{tabular}

The results the above study shows that all items were accepted by the respondents. The respondents agreed much on (3.55) hardly eat twice a day, (3.40) lack required food nutrients like proteins, vitamins and minerals (3.39) illness as a result of low food calories respectively.

\section{DISCUSSION}

The findings on social life of children in IDP is in line with the study of Johnson (2014) who noted that children in IDP camp experience poor social life such as high level of discrimination and stigmatization due to poor dressing, language barrier, lack of education among others . According to Danjuma \& Stephen (2018), this menace and their manifestation are not good for the child and have left a lot of the children in the camps with problems of lower sense of self-worth, inability to relate with peers, reduced attention, learning disorder, depression, excessive anxiety, dissociative identity, behavioural problems and acts of juvenile delinquencies

The findings on financial challenges in table two above is in line with Akande (2003) who established that financial challenges are the problems of the families of children in IDPs camps. Financial problems encountered by these children includes inadequate finance, high level of poverty, lack of employment, limited access to economic activities, unmet health problem due to lack of finance and lost of gainful employment among others. Poverty in the camp has a devastating effect and has played a role in impelling the menace of child abuse. It is as a result of poverty related factors such as poor malnutrition; infant mortality rate among the children in most of the camps are high than average and life expectancy rates are lower than average. Other effects of poverty as manifested in the camps are the infectious diseases (Measles, Cholera, eczema, diarrhea, and e.t.c.) .

The findings on feeding pattern is in line with the study of Ahmed (2017) who stated that, malnutrition, wrong time of eating, eating of much starchy food, starvation and lack of access to portable water among others are all challenges faced by children living in IDP camps. The study also agrees with the findings of Azam (2009) who opined that incidence of malnourishment, starvation, hunger and spread of infections associated with poverty such as Beriberi, kwashiorkor, thiamine infections and deficiency, gastrointestinal disorder, stunted growth, poor mental development, depression and as well infections such as measles, cholera, diarrhea and lot of others have adverse effect on the child personality, self esteem and worth, and the functional well being of the child. According to Clark (2018) in his Meta - 
analysis of the condition of children in IDPs in Nigeria stressed that most of the camping areas in Nigeria and most especially in Benue state, are characterized by conditions such as inadequate basic needs like foods, congestion, issue of children rape, spread of infections, human right abuse, child death, starvation and social vices where women and young girls prostitute to make ends meet.

\section{CONCLUSION}

From the findings of the study, it has observed that the challenges confronting internally displaced children in Makurdi metropolis of Benue State calls for an urgent attention. The denier of these Children basic rights is the major cause of these challenges. Conclusively, insecurity challenges should be tackled by government to ensure that household return to their various communities

\section{Recommendation/ Solutions}

Based on the outcome of the study, the following recommendations are made.

1. Improvement of social life of internally displaced children should be given uppermost attention the government and non- government organisations responsible for child upbringing.

2. The governments should make frantic effort to ensure adequate provision of basic amenities such as water, food and shelter. Emergency healthcare and education (schools) should be provided in IDPs camps

3. Good food should be provided for children in internally displaced camps to avoid malnutrition that leads to ill health

4. Causes insecurity and other crisis that leads to displacement of families should be given lasting solutions by government and communities concerned.

5. The Children should be encouraged to adopt a good environmental sanitation which will go a long way to help prevent them from contracting some sickness and disease.
6. The rights of these children should be acknowledged by both state and federal government as well as other individuals as this will enable them to do better in the future.

\section{Further Studies}

This study serves as a basis for further research study on challenges of internally displaced Children in Makurdi metropolis of Benue State, Nigeria.

Similar studies should be conducted in other states in other nations so as to bring about lasting solutions to insecurity and other communal crisis that leads to displacement of households.

\section{Acknowledgement: None}

\section{Conflict of Interest: None}

\section{Source of Funding: None}

\section{REFERENCES}

1. Adamu, A., and Rasheed, Z. H. (2016).Effects of Insecurity on the Internally Displaced Persons (IDPs) in Northern Nigeria: Prognosis and Diagnosis. Global Journal of Human-Social Science: Political Science, 16(1), 10-21.

2. Ahmed, H. (2017) .Officials and citizens in international relationships: the Dartmouth conference. in volkan, J. Montville, D and Juluis A, Eds. The Psychodynamics of international relations Lexington: Lexington Books.

3. Akande, Y. (2003). An Agenda for Peace. New York. United Nations.

4. Akuto, W. G (2017). Challenges of Internally Displaced Persons (IDPs) in Nigeria: Implications for Counselling and the Role of Key Stakeholders; International Journal of Innovative Psychology \& Social Development 5(2):21-27 ISSN: 2467-8546

5. Azam, J.P. (2009). Betting on Displacement: Oil, violence, and the Switch to Civilian Rule in Nigeria

6. Bonnet, M. (2010). Child Labour and the Industrial Revolution. Bloomington: Indiana University Press.

7. Centre Disease control for Children International (2009). International Investigation into the Rights of Abandoned 
Children. Geneva: Defense for Children International.

8. Clark, N. (2015). Child Labour and the Industrial Revolution. Bloomington: University Press.

9. Cinjel, D and Akende, J. (2015) . An Assessment of Conflict in Barkin Ladi Area of Plateau State. A.B.U Journal of Public Administration.

10. Desai and Kulkarni, O. (2008). changing educational inequality demography, 45,245270

11. Dickson, N.C, Danjuma, J. and Stephen, G.E (2018). An Appraisal OF the incidences of child abuse among the internally displaced persons (Idps) In Benue State, Nigeria

12. Falobi, F. (2014). Nigeria: Coping with challenges of internally displaced persons. Allafrica. Available from: www.m.allafrica.com [Accessed 15 August, 2014.]

13. GRID (2016). Global Report on Internal Displacement. IDMC. May.www.internaldisplacement.org/.../2016-global-reportinternal-displacement-IDMC.pdf.

14. Johnson, Y. (2014).State of the Worlds Refugees: the challenges of protection.York: Penguin books.
15. Ode, E. (2018). Internally displaced persons (IDPs) in Guma local government area of Benue state and their information needs.

16. Okoli, A. C., and Iortyer, P. (2014). Terrorism and Humanitarian Crisis in Nigeria: Insights from Boko Haram Insurgency. Global Journal of HumanSocial Science: Political Science, 14(1),3949.

17. Omale, C (2012). Information needs of rural farmers in Apa Local Government Area. B.Sc.Project Benue state university, Makurdi (unpublished).

18. Talja, S. (2015) .Constituting "Information" and "users" as Reasearch objects:A theory of knowledge formations as an Alternative to the information Mantheory.Perttivakkari,Reijosarolianen and Brenda Dervin (eds) information seeking in context London: Taylor Graham.

How to cite this article: Okonkwo L.E, Nomji, E,V. Challenges of internally displaced children in Makurdi Metropolis of Benue State. International Journal of Research and Review. 2021; 8(10): 314-319. DOI: https://doi.org/10. 52403/ijrr.20211042 